DIGITAL COMMONS
@ UNIVERSITY OF SOUTH FLORIDA

Volume 8

Issue 2 Volume 8, Issue 2 Fall 2018

\section{ABO: Interactive Journal for Women in the Arts, 1640-1830}

2018

\title{
Review of Royal Shakespeare Company Production of Mary Pix's The Beau Defeated, retitled The Fantastic Follies of Mrs. Rich
}

Aparna Gollapudi

Colorado State University - Fort Collins, aparna.gollapudi@colostate.edu

Follow this and additional works at: https://digitalcommons.usf.edu/abo

Part of the Dramatic Literature, Criticism and Theory Commons, Educational Methods Commons, Feminist, Gender, and Sexuality Studies Commons, and the Literature in English, British Isles Commons

\section{Recommended Citation}

Gollapudi, Aparna (2018) "Review of Royal Shakespeare Company Production of Mary Pix's The Beau Defeated, retitled The Fantastic Follies of Mrs. Rich," ABO: Interactive Journal for Women in the Arts, 1640-1830: Vol.8: Iss.2, Article 4. https://doi.org/10.5038/2157-7129.8.2.1197

Available at: https://digitalcommons.usf.edu/abo/vol8/iss2/4

This Reviews is brought to you for free and open access by Digital Commons @ University of South Florida. It has been accepted for inclusion in ABO: Interactive Journal for Women in the Arts, 1640-1830 by an authorized administrator of Digital Commons @ University of South Florida. For more information, please contact digitalcommons@usf.edu. 


\title{
Review of Royal Shakespeare Company Production of Mary Pix's The Beau Defeated, retitled The Fantastic Follies of Mrs. Rich
}

\begin{abstract}
Jo Davies's reprise of Mary Pix's comedy The Beau Defeated, Or The Lucky Younger Brother,performed by the Royal Shakespeare Company at Swan Theatre in Stratford-upon-Avon under the title The Fantastic Follies of Mrs. Rich refocuses the comedy from its original engagement with primogeniture and middling class masculinity towards the female characters. It also diffuses Pix's Whiggish moralism in Mrs. Rich's portrayal, highlighting instead her energy and verve. Overall, a very successful production, the performance is more Restoration comedy than the transitional work that Pix's play was when it opened in 1700.
\end{abstract}

\section{Keywords}

Pix, comedy, performance

\section{Creative Commons License}

cc) (1) (8)

This work is licensed under a Creative Commons Attribution-Noncommercial 4.0 License 
Review of Royal Shakespeare Company Production of Mary Pix's The Beau Defeated, retitled The Fantastic Follies of Mrs. Rich (Swan Theatre, Stratford-upon-Avon, April-June 2018).

Aparna Gollapudi

Colorado State University

A shrill and comically exaggerated wail pierces the theatre, followed immediately by a footman staggering onstage, nearly collapsing under the weight of the elaborately periwigged woman he carries and almost obscured by the wayward layers of her hooped petticoat. Mrs. Rich has entered the building.

And she will dominate the stage over the next few hours as Jo Davies' reprise of Mary Pix's comedy The Beau Defeated, Or The Lucky Younger Brother, unfolds in Swan Theatre at Stratford-upon-Avon under the title The Fantastic Follies of Mrs. Rich. Pix's successful play, which opened in 1700, features two wealthy widows search of new husbands-Lady Landsworth pursues the disenfranchised younger brother, Younger Clerimont, to assure herself that he is indeed as honest as he is handsome, while Mrs. Rich is determined to marry into aristocracy so that she no longer stinks of the shop. The play includes many classic elements of Restoration comedy, such as the amorous widow, the bumbling country squire, and the extravagant fop; but it also looks forward to eighteenth-century comedy in its valorization of sober moderation, moral behavior, and economic prudence. As a transitional work written by a Whiggish playwright in the Williamite era, the comedy's ideological force primarily comes from Pix's revisionist approach to contemporary hegemonic masculinities. She critiques primogeniture in her portrayal of the Clerimonts, where the foolish older brother inherits all and the worthy "younger brother" of the title is deprived of even bare sustenance because of the accident of birth. In Sir John Roverhead, the false "beau defeated," she mocks fashionable aristocratic masculinity, contrasting it with middling class men, who are "substantial in their persons, their purses, their credits" (II.ii.199-200). Pix's socio-political worldview also informs her portrayal of the two contrasting widows in her play, both rich, financially independent, and amorous - but one, Lady Landsworth, is witty and in search of a modest, virtuous man, while the other, Mrs. Rich, is silly and shallowly pursuing the tinseled glamor of an aristocratic title.

In shaping this politically-nuanced comedy written more than three hundred years ago for the delight of a modern audience, Davies turns away from Pix's rhetorical engagement with competing models of masculinity and focuses instead on the power and dynamism of her female characters. Also, while remaining true to Pix's presentation of contrasting femininities in the two widows, the production diffuses some of the socio-moral disapproval that she directs towards Mrs. Rich with the use of humor. Often, figures full of comic energy who provoke laughter in the theatre prove to be the enduring favorites, even though it is their folly that creates mirth. This is certainly the case in the RSC's re-visioning of Pix's women in the play-while the "good" widow, Landsworth, played by Daisy Badger, remains a charming and lively iteration of empowered femininity, it is Sophie Stanton's portrayal of the eponymous "bad" widow's fantastic follies which power this delightful production. Indeed, Davies' focus on the termagant Mrs. Rich is very much of a piece with her directorial fascination with transgressive women, as evidenced by her well-received productions of John Middleton's The Roaring Girl played in more modern dress, and her Kiss Me Kate, Cole Porter's twist on The Taming of the Shrew. The 
set and costumes of Fantastic Follies are consonant with Davies' attempts to effectively reorient this centuries old play to contemporary taste. The stage set works as a quick thumbnail sketch blending functionality, historicity, and symbolism-Young Clerimont's poor apartment is dominated by a bed for the mopey hero, Mrs. Rich's parlor has ornate sofas, card-tables and mirrors, while the graciously genteel Mrs. Clerimont's home houses delicate glass cases with flowers. Similarly, the costuming conveys a strongly Restoration flavor-especially in Mrs. Rich's elaborate gowns and wig - while the ruffled shirts and pantaloons of Younger Clerimont or Belvoir more loosely evoke clothing of years past.

In glancing away from the dramatic centrality of the "Beau Defeated" and the "Lucky Younger Brother" as thematic focal points, the RSC production ends up revealing interesting comic potential in Younger Clerimont's character. As the hero of Pix's comedy, he represents an idealized sort of masculinity - an honorable and cultivated young man, who is modest and genteel even in the midst of a temptingly desirable as well as profitable amour. He is an incarnation of the post-revolution comic hero type that Richard Braverman terms "honnete homme" (213). Certainly, on the page, he appears a rather pitiable figure, suddenly crushed by the twist of fate that has left his father dead and him penniless. But in Davies' production, Younger Clerimont, played by Solomon Israel, emerges not as a laudable figure but as comically whiny and passive. Though a decent enough and rather likeable sort of fellow, Younger Clerimont's self-pitying melancholy, played up by Israel to great effect, is hilarious. Indeed, in the text too, the agency, spirit, and control of Lady Landsworth stands out when juxtaposed with her lover's passivity; but in this performance the frequency with which Clerimont moans out, "What a wretch am I!" or some similar sentiment is a rather startling revelation of the comic potential written into this character by Pix. While the presentation of Younger Clerimont's character as a self-indulgent melancholic might not be of a piece with Pix's dramatic design, it definitely enhances this particular take on The Beau Defeated, which transforms the comedy into The Fantastic Follies of Mrs. Rich.

Though technically this production retains most of Pix's plot and dialogue, the retitling focuses attention on Mrs. Rich's story, making her the protagonist of the play. Visually she is an impressive presence on the stage, with her rich gowns, elaborate wig, and frequent wardrobe change. Indeed, Sir John Roverhead - rather uncharacteristically for a fop figure-pales into insignificance before her. In addition, she is given many catchy songs, which Sophie Stanton belts out with skill and verve. For instance, a song with the refrain, "Woman of Quality," captures wonderfully Mrs. Rich's fetishization of upper-class identity but it also raises her from a mere caricature of an ambitious city wife to a witty and talented woman. Similarly, in her "duel" with Mrs. Trickwell (who transposes La Bassett in the performance), when Mrs. Rich snatches a long feather duster to fight back her opponent's 'aristocratic' challenge to her honor, the gesture reinforces her lowly class origins even as her energetic ripostes raise not only our laughter but also a grudging respect at the widow's refusal to be cowed. Even in her confrontation with Mr. Rich, though the excoriating criticism her brother-in-law levies at her is retained in the performance, Stanton's pert sassiness prevents the worst of the insults from sticking, as we laugh at her subversion of his pompous seriousness. And at her lowest point in the play-when she finds out she's been tricked into marrying a boorish country squire - the fall is softened by the conciliatory gestures of deference by the rest of the company who exaggeratedly scrape and bow as they reassure her that in marrying Elder Clerimont, she is indeed marrying up and will soon 
gain a title. Thus, she not only seems to go scot-free despite her "fantastic follies" but even gets to sing the final ditty advising her niece, Lucinda to "Marry Well!" significantly supplanting Mr. Rich's closing song in Pix's text that warns foolish women to be "forever cautious of your conversation" (V.iii.449-50) while directing the highest praise "to our citizens, Augusta's sons" (V.iii.455).

Pix's play has significant proto-feminist potential, especially as manifested in the character of Lady Landsworth, who embodies the intelligent self-determination and sensible amatory choices an independent widow is capable of when she has power over her personal and economic choices. However, in the case of Mrs. Rich, Pix is less generous. The Whiggish value system Pix endorses in her play requires that she exorcise and revise Restoration comedy tropes of cit wives seduced by the glamour of aristocratic beaus while rehabilitating prosperous, moral, and respectable middling class masculinity as the emulable standard. The RSC performance, unshackled from turn of the century concerns with inheritance law and party politics, reincarnates Mrs. Rich's simply as an intriguing "wealthy widow on her way up." In doing so, it makes her - and Pix's comedy - more accessible to modern viewers because that motif is familiar enough still. The production thus tends to flatten the generically transitional nature of Pix's comedy which, though technically a Restoration comedy, also anticipates the more moralsentimental comic strain of the following decades. But, in the process it also frees poor Mrs. Rich from the anxious censure her class ambitions attracted in 1700 so that present-day audiences can freely enjoy her extravagant spirit and relentless self-advancement.

On the whole, this is an exuberant production - with scenes such as Sir John Roverhead mounted on Lucinda "discovered" under the tablecloth as he seduces the bouncing young girl, it seems more Restoration comedy in essence than Pix's original play. But the fine acting and exciting stage business, such as the prancing about of Elder Clerimont's dogs on stage, makes it an excellent theatrical experience and a welcome revival of this lesser-known woman playwright's work. 


\section{Works Cited}

Braverman, Richard. Plots and Counterplots: Sexual Politics and the Body Politic in English Literature, 1660-1730. New York: Cambridge UP, 1993.

Pix, Mary. The Beau Defeated or The Lucky Younger Brother in The Broadview Anthology of Restoration and Early Eighteenth-Century Drama, ed. Douglas Canfield. Broadview, 2002, pp. 810-56. 